\title{
Amorphus orientalis sp. nov., an exopolysaccharide-producing bacterium isolated from salt mine sediment
}

\author{
Correspondence \\ Xiao-Long Cui \\ xlcuiynu@yahoo.com.cn or \\ xlcui@ynu.edu.cn
}

\author{
Yong-Xia Wang, ${ }^{1}{ }^{\dagger} \mathrm{Ji}-\mathrm{Hui} \mathrm{Liu},{ }^{1} \dagger$ Yi-Guang Chen, ${ }^{1,2}$ Xiao-Xia Zhang, ${ }^{3}$ \\ Zhi-Gang Wang, ${ }^{1}$ Yun Chen, ${ }^{1}$ Shi-Ping Tian, ${ }^{1}$ Bin $\mathrm{Hu}^{1}$ and Xiao-Long Cui ${ }^{1}$ \\ ${ }^{1}$ Yunnan Institute of Microbiology, Yunnan University, Kunming, Yunnan 650091, PR China \\ ${ }^{2}$ College of Bio-resources and Environmental Science, Jishou University, Jishou, Hunan 416000 , \\ PR China \\ ${ }^{3}$ Agricultural Cultural Collection of China, Institute of Agricultural Resources and Regional Planning, \\ Chinese Academy of Agricultural Sciences, Beijing 100080, PR China
}

A Gram-negative, moderately halophilic, non-motile, aerobic bacterium, designated strain YIM $\mathrm{D} 10^{\top}$, was isolated from a salt mine sediment sample from Yunnan, south-west China. The strain grew optimally in the presence of $3-8 \% \mathrm{NaCl}$ and at $28{ }^{\circ} \mathrm{C}$ and $\mathrm{pH} 7.5$. The polar lipid profile of strain YIM D10 ${ }^{\top}$ comprised diphosphatidylglycerol, an unknown phospholipid and two unknown aminolipids. The major cellular fatty acids were $\mathrm{C}_{18: 1} \omega 7 \mathrm{c}(30.5 \%), \mathrm{C}_{19: \mathrm{o}}$ cyclo $\omega 8 c(29.3 \%)$ and $C_{18: 0}(13.2 \%)$. The respiratory quinone was ubiquinone $10(\mathrm{Q}-10)$. The genomic DNA G + C content was 65.4 mol\%. Phylogenetic analysis based on 16S rRNA gene sequences showed that strain YIM D10 ${ }^{\top}$ was closely related to Amorphus coralli RS.Sph.026 ${ }^{\top}$ ( $96.8 \%$ gene sequence similarity). Results confirmed the placement of isolate YIM D10 ${ }^{\top}$ within the genus Amorphus. However, DNA-DNA hybridization between strain YIM D10 ${ }^{\top}$ and the type strain of the only recognized species of the genus Amorphus, A. coralli RS.Sph.026 ${ }^{\top}$, was $16.7 \%$, showing clearly that the isolate constitutes a new genospecies. Strain YIM D10 ${ }^{\top}$ could be clearly differentiated from $A$. coralli and other phylogenetic neighbours on the basis of some phenotypic, genotypic and chemotaxonomic features. Therefore, strain $\mathrm{YIM} \mathrm{D10}{ }^{\top}$ is considered to represent a novel species of the genus Amorphus, for which the name Amorphus orientalis sp. nov. is proposed; the type strain is YIM D10 $0^{\top}$ (=DSM $21202^{\top}=$ CCTCC AA $208035^{\top}$ ).
Taxonomically, the majority of the Gram-negative halophilic bacteria belong to the class Gammaproteobacteria, but they can also be found in other bacterial groups (Ventosa et al., 1998), such as the genera Salipiger (Martínez-Cánovas et al., 2004) and Palleronia (Martínez-Checa et al., 2005) of the class Alphaproteobacteria. The genus Amorphus was proposed by Zeevi Ben Yosef $e t$ al. (2008) to accommodate a Gram-negative, non-motile, halotolerant bacterium with cells that differed morphologically. At the time of writing, the genus comprised only one recognized species, Amorphus coralli, which was isolated from mucus of the coral Fungia granulosa collected from the northern Red Sea. The major fatty acids in this species were $\mathrm{C}_{18: 1} \omega 7 c$ and $\mathrm{C}_{19: 0}$ cyclo $\omega 8 c$

†These authors contributed equally to this work.

The GenBank/EMBL/DDBJ accession number for the 16S rRNA gene sequence of strain YIM D10 ${ }^{\top}$ is FJ998414.

A transmission electron micrograph of cells of strain YIM D10 ${ }^{\top}$ is available as a supplementary figure with the online version of this paper. and the DNA $\mathrm{G}+\mathrm{C}$ content of the type strain was $67.1 \mathrm{~mol} \%$. The aim of this study was to determine the exact taxonomic position of strain YIM D10 ${ }^{\mathrm{T}}$ by using a polyphasic approach.

During an investigation of the cultured microbial diversity of a salt mine in Yunnan, south-west China, strain YIM $\mathrm{D} 10^{\mathrm{T}}$ was isolated from a sediment sample collected from the Fenggang salt mine using a standard dilution-plating technique on marine agar 2216 (MA, pH 7.2; Difco) incubated at $28{ }^{\circ} \mathrm{C}$ for 3 weeks. Strain YIM D10 ${ }^{\mathrm{T}}$ was isolated and subsequently purified four times both on MA and trypticase soy agar (TSA; Difco) supplemented with $3 \%(\mathrm{w} / \mathrm{v}) \mathrm{NaCl}$ at $28{ }^{\circ} \mathrm{C}$. Strain YIM D10 ${ }^{\mathrm{T}}$ was maintained on TSA supplemented with $3 \% \mathrm{NaCl}$ at $28{ }^{\circ} \mathrm{C}$ (referred to henceforth as 'maintenance medium') and stored as $20 \%$ $(\mathrm{v} / \mathrm{v})$ glycerol suspensions at $-80{ }^{\circ} \mathrm{C}$. For phenotypic characterization and fatty acid profile comparison, $A$. coralli RS.Sph. $026^{\mathrm{T}}$ was grown on TSA supplemented with $3 \%(\mathrm{w} / \mathrm{v}) \mathrm{NaCl}$ and used as a reference strain. 
Morphological and physiological tests were performed as follows. Gram staining was carried out by using the standard Gram reaction combined with the $\mathrm{KOH}$ lysis test method (Gregersen, 1978). Motility was observed via the hanging-drop method (Suzuki et al., 2001) and staining of flagella was carried out according to Blenden \& Goldberg (1965) and observed by light microscopy (BH-2; Olympus). Cell morphology was observed by transmission electron microscopy. Growth at various salt concentrations was determined on TSA supplemented with $\mathrm{NaCl}$ at $0,0.5,1,2$, $3,5,7,10,12,15,20,25$ and $30 \%(\mathrm{w} / \mathrm{v})$. Growth at different $\mathrm{pH}$ values ( $\mathrm{pH} 5-10$, in increments of 0.5$)$ and temperatures $\left(4,10,15,20,25,28,37,42,45,50\right.$ and $\left.55^{\circ} \mathrm{C}\right)$ was determined on maintenance medium. Growth under anaerobic conditions was determined after incubation in an anaerobic jar (GasPak Anaerobic systems; BBL) on maintenance medium. Photosynthetic and carotenoid pigments were analysed by using a methanol/acetone mixture $(1: 1, \mathrm{v} / \mathrm{v})$ and a scanning UV/visible spectrophotometer (Biospec-1601; Shimadzu). For exopolysaccharide recovery, cells were incubated and centrifuged at the stationary growth phase; supernatants were treated and analysed as reported by Manca et al. (1996). Catalase and oxidase activities were determined by using $3 \%(\mathrm{v} / \mathrm{v})$ hydrogen peroxide and Kovacs' reagent (Kovacs, 1956), respectively. L-Phenylalanine deamination was examined using the method of Richard \& Kiredjian (1995). Citrate utilization was tested on Simmons' citrate agar (Sigma). $\mathrm{H}_{2} \mathrm{~S}$ production was determined on Kligler iron agar (Difco). Methyl red and Voges-Proskauer tests were performed as described by Smibert \& Krieg (1994). Nitrate reduction, hydrolysis of aesculin and gelatin, acid production from glucose, indole production, and arginine dihydrolase, urease, $\beta$-galactosidase and other enzyme activities were tested using the API 20NE and API ZYM kits (bioMérieux) according to the manufacturer's instructions. For all of these tests, cell suspensions were supplemented with $5 \%(\mathrm{w} / \mathrm{v}) \mathrm{NaCl}$. Carbon source utilization was tested by using the Biolog GN2 system. Antibiotic resistance was determined by the disc diffusion method using commercial antibioticimpregnated discs.

Isoprenoid quinones were extracted by using the method of Collins et al. (1977) and analysed by HPLC as described by Tamaoka et al. (1983). Polar lipids were extracted according to the procedures described by Minnikin et al. (1979) and identified by two-dimensional TLC after spraying with the appropriate detection reagents (Collins \& Jones, 1980). Biomass for quantitative fatty acid analysis was obtained by scraping cells from plates of maintenance medium that had been incubated for 5 days at $28{ }^{\circ} \mathrm{C}$. Analysis of the cellular fatty acid pattern followed the method described by Sasser (1990) using the Microbial Identification System (MIDI). The G $+\mathrm{C}$ content of the genomic DNA was determined by HPLC according to Mesbah et al. (1989), after DNA extraction by the method of Cui et al. (2001); the genomic DNA of Escherichia coli DH5 $\alpha$ was used as a standard.
The 16S rRNA gene was amplified and sequenced as described by Cui et al. (2001). The almost-complete $16 \mathrm{~S}$ rRNA gene sequence (1385 nt) of strain YIM D10 ${ }^{\mathrm{T}}$ was obtained and compared with available 16S rRNA gene sequences in GenBank by using BLAST searches (Altschul et al., 1990). Alignments and similarities were obtained by the CLUSTAL_X program (Thompson et al., 1997). The phylogenetic tree was constructed by using the neighbourjoining (Saitou \& Nei, 1987) and maximum-parsimony (Fitch, 1971) methods with MEGA4 (Tamura et al., 2007). Bootstrap analysis was used to evaluate tree topology of the neighbour-joining data by means of 1000 resamplings (Felsenstein, 1985).

Strain YIM $\mathrm{D} 10^{\mathrm{T}}$ was a Gram-negative, non-motile and aerobic bacterium; cells were rod-shaped structures of 1.0$2.5 \mu \mathrm{m}$ in length that differed morphologically (see Supplementary Fig. S1, available in IJSEM Online). The isolate was moderately halophilic, showing optimal growth

Table 1. Differential characteristics of strain YIM D $10^{\top}$ and its phylogenetically closest neighbour

Strains: 1 , YIM D $10^{\mathrm{T}} ; 2$, A. coralli RS.Sph. $026^{\mathrm{T}}$. Data from this study unless otherwise indicated. Both strains were Gram-negative and positive for catalase, alkaline phosphatase, butyrate esterase (C4), caprylate esterase (C8), leucine arylamidase, valine arylamidase, cystine arylamidase, $\alpha$-chymotrypsin, trypsin, naphthol-AS-BI-phosphohydrolase, acid phosphatase, arginine dihydrolase, urease, and utilization of L-arabinose, $\alpha$-cyclodextrin, dextrin, $\alpha$-D-glucose, maltose, D-mannose, $\beta$-hydroxybutyric acid, succinic acid monomethyl ester and succinic acid. +, Positive; -, negative.

\begin{tabular}{|c|c|c|}
\hline Characteristic & 1 & 2 \\
\hline Origin & Salt mine & Red Sea* \\
\hline Cell size $(\mu \mathrm{m})$ & $1.0-2.5$ & $0.5-3.0^{*}$ \\
\hline Temperature range for growth $\left({ }^{\circ} \mathrm{C}\right)$ & $15-37$ & $22-37^{\star}$ \\
\hline $\mathrm{pH}$ range for growth & $6.5-8.5$ & $6.0-10.0^{*}$ \\
\hline Nitrate reduction & - & + \\
\hline \multicolumn{3}{|l|}{ Hydrolysis of: } \\
\hline Aesculin & - & + \\
\hline Gelatin & + & - \\
\hline \multicolumn{3}{|l|}{ Substrates utilized (Biolog GN2) } \\
\hline Acetic acid & + & - \\
\hline D-Arabinose & - & + \\
\hline L-Asparagine & - & + \\
\hline Cellobiose & - & + \\
\hline D-Fructose & - & + \\
\hline Glycerol & + & - \\
\hline DL-Lactic acid & - & + \\
\hline D-Mannitol & + & - \\
\hline Sucrose & + & - \\
\hline \multicolumn{3}{|l|}{ Enzyme activity (API ZYM) } \\
\hline$\alpha$-Galactosidase & + & - \\
\hline Myristate lipase (C14) & + & - \\
\hline DNA $G+C$ content $(\mathrm{mol} \%)$ & 65.4 & $67.1^{\star}$ \\
\hline
\end{tabular}

${ }^{\star}$ Data from Zeevi Ben Yosef et al. (2008). 
Table 2. Cellular fatty acid composition of strain YIM D10 and its phylogenetically closest neighbour

Strains: 1, YIM D10 $0^{\mathrm{T}} ; 2$, A. coralli RS.Sph. $026^{\mathrm{T}}$. Data for both strains were from this study. Values are percentages of the total fatty acids. - , Not detected.

\begin{tabular}{|lcc|}
\hline Fatty acid & $\mathbf{1}$ & $\mathbf{2}$ \\
\hline $\mathrm{C}_{9: 0}$ & 0.2 & - \\
$\mathrm{C}_{12: 0}$ & 0.3 & - \\
$\mathrm{C}_{14: 0}$ & 0.4 & - \\
$\mathrm{C}_{16: 0}$ & 3.2 & 9.2 \\
$\mathrm{C}_{17: 0}$ & 2.3 & - \\
$\mathrm{C}_{18: 0}$ & 13.2 & 10.1 \\
$\mathrm{C}_{19: 0}$ & 0.7 & - \\
iso-C $17: 1$ & 1.1 & - \\
$\mathrm{C}_{18: 0} 3-\mathrm{OH}$ & 0.6 & - \\
$\mathrm{C}_{17: 1} \omega 7 c$ & 0.7 & - \\
$\mathrm{C}_{18: 1} \omega 7 c$ & 30.5 & 43.4 \\
$\mathrm{C}_{20: 1} \omega 7 c$ & 8.6 & 15.4 \\
$\mathrm{C}_{20: 2} \omega 6,9 c$ & 1.2 & - \\
$11-$ methyl- $\mathrm{C}_{18: 1} \omega 7 c$ & 7.9 & - \\
$\mathrm{C}_{19: 0}$ cyclo $\omega 8 c$ & 29.3 & 21.9 \\
\hline
\end{tabular}

at $3-8 \%(\mathrm{w} / \mathrm{v}) \mathrm{NaCl}$, and was able to grow in media with 0.5-12\% (w/v) NaCl. Cells produced exopolysaccharide. No photosynthetic or carotenoid pigment was detected. Other phenotypic characteristics of strain YIM D $10^{\mathrm{T}}$ are given in Table 1 and the species description.

The cellular fatty acid profiles of strain YIM D10 $0^{\mathrm{T}}$ (Table 2) and A. coralli RS.Sph. $026^{\mathrm{T}}$ were analysed in this study. The major fatty acids of strain YIM D10 ${ }^{\mathrm{T}}$ were similar to those of A. coralli RS.Sph. $026^{\mathrm{T}}$ in that $\mathrm{C}_{18: 1} \omega 7 c, \mathrm{C}_{20: 1} \omega 7 c, \mathrm{C}_{19: 0}$ cyclo $\omega 8 c$ and $\mathrm{C}_{18: 0}$ were the predominant fatty acids, but there were also differences in the proportions of some fatty acids, particularly 11-methyl $\mathrm{C}_{18: 1} \omega 7 c, \mathrm{C}_{20: 1} \omega 7 c$ and
$\mathrm{C}_{16: 0}$. The major polar lipids of strain YIM D10 ${ }^{\mathrm{T}}$ were diphosphatidylglycerol, one unknown phospholipid and two unknown aminolipids. The genomic DNA $\mathrm{G}+\mathrm{C}$ content was $65.4 \mathrm{~mol} \%$.

Strain YIM D10 ${ }^{\mathrm{T}}$ was affiliated phylogenetically to the genus Amorphus. In the neighbour-joining phylogenetic tree based on $16 \mathrm{~S}$ rRNA gene sequences, strain YIM D10 ${ }^{\mathrm{T}}$ joined the lineage comprising the type strain of $A$. coralli at a bootstrap value of $100 \%$ (Fig. 1). The relationship between strain YIM D10 ${ }^{\mathrm{T}}$ and A. coralli RS.Sph. $026^{\mathrm{T}}$ was maintained in a tree based on the maximum-parsimony algorithm (Fig. 1). Strain YIM D10 ${ }^{\mathrm{T}}$ exhibited 16S rRNA gene sequence similarities of $96.8 \%$ to $A$. coralli RS.Sph. $026^{\mathrm{T}}$ and similarities of less than $93.4 \%$ to strains of other species included in the phylogenetic analysis. DNA-DNA hybridization experiments between strain YIM $\mathrm{D} 10^{\mathrm{T}}$ and A. coralli RS.Sph. $026^{\mathrm{T}}$ were performed using the optical renaturation method (De Ley et al., 1970; Huß et al., 1983; Jahnke, 1992). The hybridization value of the two strains was $16.7 \%$.

The combination of phylogenetically coherent clustering and the cellular fatty acid profiles indicated that strain YIM $\mathrm{D} 10^{\mathrm{T}}$ was a member of the genus Amorphus. However, it could be differentiated readily from $A$. coralli based on several phenotypic characteristics (Table 1): the ability to grow at $15{ }^{\circ} \mathrm{C}$ (Zeevi Ben Yosef et al., 2008); a different $\mathrm{pH}$ range for growth (i.e. 6.5-8.5 and 6.0-10.0 for strain YIM $\mathrm{D} 10^{\mathrm{T}}$ and $A$. coralli RS.Sph. $026^{\mathrm{T}}$, respectively); nitrate reduction; hydrolysis of aesculin and gelatin; and utilization of D-arabinose, cellobiose, D-fructose, D-mannitol, sucrose, acetic acid, D- and L-lactic acid, L-asparagine and glycerol. Based on the phenotypic and genotypic differences between strain YIM D10 ${ }^{\mathrm{T}}$ and its closest relative, strain YIM D10 ${ }^{\mathrm{T}}$ represents a novel species of the genus Amorphus, for which the name Amorphus orientalis sp. nov. is proposed.

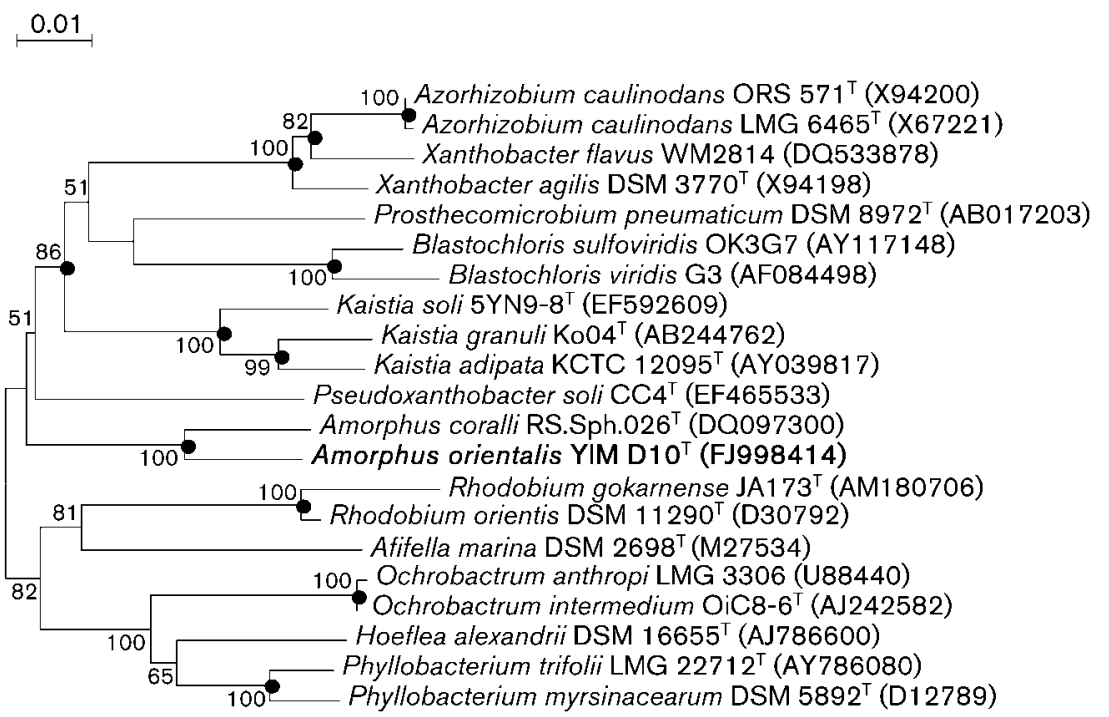

Fig. 1. Neighbour-joining phylogenetic tree based on 16S rRNA gene sequences showing the relationships between strain $\mathrm{YIM} \mathrm{D}^{\top} 0^{\top}$ and A. coralli RS.Sph.026 ${ }^{\top}$ and members of related genera. Bootstrap values (\%; based on 1000 replications) $>50 \%$ are shown at branching points. Filled circles indicate that the corresponding nodes were also recovered in the tree generated with the maximumparsimony method. Bar, 0.01 substitutions per nucleotide position. 


\section{Description of Amorphus orientalis sp. nov.}

Amorphus orientalis (o.ri.en.ta'lis. L. masc. adj. orientalis eastern, bacterium inhabiting the east).

Colonies are cream-white, smooth, circular, convex and opaque with entire edges. Cells are Gram-negative, catalase-positive, oxidase-negative, non-motile, rod-shaped structures of $1.0-2.5 \mu \mathrm{m}$ in length that differ morphologically. Temperature range for growth is $15-37^{\circ} \mathrm{C}$; optimum is $28{ }^{\circ} \mathrm{C}$. $\mathrm{pH}$ range for growth is 6.5-8.5; optimum is 7.5. Growth occurs at $\mathrm{NaCl}$ concentrations of $0.5-12 \%(\mathrm{w} / \mathrm{v})$. Positive for urease, arginine dihydrolase and gelatin hydrolysis. Negative for aesculin hydrolysis, nitrate reduction, glucose acidification, $\beta$-galactosidase, methyl red and Voges-Proskauer tests, indole and $\mathrm{H}_{2} \mathrm{~S}$ production, and L-phenylalanine deaminase activity. The following carbon sources are utilized: L-arabinose, $\alpha$ cyclodextrin, citrate, dextrin, $\alpha$-D-glucose, maltose, mannitol, D-mannose, sucrose, succinic acid monomethyl ester, acetic acid, citric acid, $\beta$-hydroxybutyric acid, succinic acid and glycerol. The following carbon sources are not utilized: adonitol, D-arabitol, D-fructose, L-fructose, D-galactose, myo-inositol, D-psicose, L-rhamnose, D-sorbitol, xylitol, formic acid, D- and L-lactic acids, bromosuccinic acid, L-alaninamide, D- and L-alanine, L-alanyl glycine, Lasparagine, L-glutamic acid, L-proline, $\alpha$-hydroxybutyric acid, $\gamma$-hydroxybutyric acid, L-aspartic acid, L-ornithine, glycogen, Tweens 40 and $80, \mathrm{~N}$-acetyl-D-galactosamine, $\mathrm{N}$ acetyl-D-glucosamine, cellobiose, $i$-erythritol, gentiobiose, $\alpha$-D-lactose, lactulose, melibiose, methyl $\beta$-D-glucoside, raffinose, trehalose, turanose, pyruvic acid methyl ester, cis-aconitic acid, D-galactonic acid lactone, D-galacturonic acid, D-gluconic acid, D-glucosaminic acid, D-glucuronic acid, $p$-hydroxyphenylacetic acid, itaconic acid, $\alpha$-ketobutyric acid, $\alpha$-ketoglutaric acid, $\alpha$-ketovaleric acid, malonic acid, propionic acid, quinic acid, D-saccharic acid, sebacic acid, succinamic acid, glucuronamide, glycyl L-aspartic acid, glycyl L-glutamic acid, L-histidine, hydroxy-L-proline, L-leucine, L-phenylalanine, L-pyroglutamic acid, D-serine, L-serine, L-threonine, D- and L-carnitine, $\gamma$-aminobutyric acid, urocanic acid, inosine, uridine, thymidine, phenylethylamine, putrescine, 2-aminoethanol, 2,3-butanediol, Dand $\mathrm{L}$ - $\alpha$-glycerol phosphate, $\alpha$-D-glucose 6 -phosphate and D-glucose 1-phosphate. Positive for the following enzyme activities: alkaline and acid phosphatases, butyrate esterase (C4), caprylate esterase (C8), myristate lipase (C14), leucine arylamidase, valine arylamidase, cystine arylamidase, $\alpha$ chymotrypsin, trypsin, naphthol-AS-BI-phosphohydrolase and $\alpha$-galactosidase. Negative for the following enzyme activities: $\beta$-galactosidase, $\beta$-glucuronidase, $\alpha$-glucosidase, $\beta$-glucosidase, $N$-acetyl- $\beta$-glucosaminidase, $\alpha$-mannosidase and $\alpha$-fucosidase. Sensitive to ( $\mu$ g per disc) novobiocin (30), gentamicin (10) and penicillin (10), but resistant to ampicillin (10), erythromycin (15), chloramphenicol (30), norfloxacin (10) and streptomycin (10).

The type strain, YIM D $10^{\mathrm{T}}\left(=\mathrm{DSM} 21202^{\mathrm{T}}=\right.$ CCTCC AA $208035^{\mathrm{T}}$ ), was isolated from a salt sediment sample collected from the Fenggang salt mine in Yunnan, southwest China. The genomic DNA G $+\mathrm{C}$ content of the type strain is $65.4 \mathrm{~mol} \%$.

\section{Acknowledgements}

This work was supported by grants from the National Natural Science Foundation of China (NSFC) (30860013, 30460004, 30660004), the Ministry of Science and Technology of China (863 Program, no. 2007AA021306), Yunnan Provincial Sciences and Technology Department (2005PY01-1, 2006C0006M, 2009DA002), and Yunnan University (2008YB005). We are grateful to Ms Ya-Ling Yang for her help during sampling, as well as Ms Xiang-Feng Cai for her excellent technical assistance.

\section{References}

Altschul, S. F., Gish, W., Miller, W., Myers, E. W. \& Lipman, D. J. (1990). Basic local alignment search tool. J Mol Biol 215, 403-410.

Blenden, D. C. \& Goldberg, H. S. (1965). Silver impregnation stain for Leptospira and flagella. J Bacteriol 89, 899-900.

Collins, M. D. \& Jones, D. (1980). Lipids in the classification and identification of coryneform bacteria containing peptidoglycans based on 2,4-diaminobutyric acid. J Appl Bacteriol 48, 459-470.

Collins, M. D., Pirouz, T., Goodfellow, M. \& Minnikin, D. E. (1977). Distribution of menaquinones in actinomycetes and corynebacteria. J Gen Microbiol 100, 221-230.

Cui, X.-L., Mao, P.-H., Zeng, M., Li, W.-J., Zhang, L.-P., Xu, L.-H. \& Jiang, C.-L. (2001). Streptomonospora salina gen. nov., sp. nov., a new member of the family Nocardiopsaceae. Int J Syst Evol Microbiol 51, 357-363.

De Ley, J., Cattoir, H. \& Reynaerts, A. (1970). The quantitative measurement of DNA hybridization from renaturation rates. Eur $J$ Biochem 12, 133-142.

Felsenstein, J. (1985). Confidence limits on phylogenies: an approach using the bootstrap. Evolution 39, 783-791.

Fitch, W. M. (1971). Toward defining the course of evolution: minimum change for a specific tree topology. Syst Zool 20, 406416.

Gregersen, T. (1978). Rapid method for distinction of Gram-negative from Gram-positive bacteria. Eur J Appl Microbiol Biotechnol 5, 123127.

Huß, V. A. R., Festl, H. \& Schleifer, K. H. (1983). Studies on the spectrophotometric determination of DNA hybridization from renaturation rates. Syst Appl Microbiol 4, 184-192.

Jahnke, K. D. (1992). BASIC computer program for evaluation of spectroscopic DNA renaturation data from GILFORD SYSTEM 2600 spectrophotometer on a PC/XT/AT type personal computer. J Microbiol Methods 15, 61-73.

Kovacs, N. (1956). Identification of Pseudomonas pyocyanea by oxidase reaction. Nature 178, 703-704.

Manca, M. C., Lama, L., Improta, R., Esposito, E., Gambacorta, A. \& Nicolaus, B. (1996). Chemical composition of two exopolysaccharides from Bacillus thermoantarcticus. Appl Environ Microbiol 62, 32653269.

Martínez-Cánovas, M. J., Quesada, E., Martínez-Checa, F., del Moral, A. \& Béjar, V. (2004). Salipiger mucescens gen. nov., sp. nov., a moderately halophilic, exopolysaccharide-producing bacterium isolated from hypersaline soil, belonging to the $\alpha$-Proteobacteria. Int J Syst Evol Microbiol 54, $1735-1740$. 
Martínez-Checa, F., Béjar, V., Martínez-Cánovas, M. J., Llamas, I. \& Quesada, E. (2005). Halomonas almeriensis sp. nov., a moderately halophilic, exopolysaccharide-producing bacterium from Cabo de Gata, Almería, south-east Spain. Int J Syst Evol Microbiol 55, 2007 2011.

Mesbah, M., Premachandran, U. \& Whitman, W. B. (1989). Precise measurement of the $\mathrm{G}+\mathrm{C}$ content of deoxyribonucleic acid by highperformance liquid chromatography. Int J Syst Bacteriol 39, 159-167.

Minnikin, D. E., Collins, M. D. \& Goodfellow, M. (1979). Fatty acid and polar lipid composition in the classification of Cellulomonas, Oerskovia and related taxa. J Appl Bacteriol 47, 87-95.

Richard, C. \& Kiredjian, M. (1995). Laboratory Methods for the Identification of Strictly Aerobic Gram-negative Bacilli. Paris: Institut Pasteur.

Saitou, N. \& Nei, M. (1987). The neighbor-joining method: a new method for reconstructing phylogenetic trees. Mol Biol Evol 4, 406425.

Sasser, M. (1990). Identification of bacteria by gas chromatography of cellular fatty acids. USFCC Newsl 20, 16.

Smibert, R. M. \& Krieg, N. R. (1994). Phenotypic characterization. In Methods for General and Molecular Bacteriology, pp. 607-654. Edited by P. Gerhardt, R. G. E. Murray, W. A. Wood \& N. R. Krieg. Washington, DC: American Society for Microbiology.
Suzuki, M., Nakagawa, Y., Harayama, S. \& Yamamoto, S. (2001). Phylogenetic analysis and taxonomic study of marine Cytophaga-like bacteria: proposal for Tenacibaculum gen. nov. with Tenacibaculum maritimum comb. nov. and Tenacibaculum ovolyticum comb. nov., and description of Tenacibaculum mesophilum sp. nov. and Tenacibaculum amylolyticum sp. nov. Int J Syst Evol Microbiol 51, 1639-1652.

Tamaoka, J., Katayama-Fujimura, Y. \& Kuraishi, H. (1983). Analysis of bacterial menaquinone mixtures by high performance liquid chromatography. J Appl Bacteriol 54, 31-36.

Tamura, K., Dudley, J., Nei, M. \& Kumar, S. (2007). MEGA4: Molecular evolutionary genetics analysis (MEGA) software version 4.0. Mol Biol Evol 24, 1596-1599.

Thompson, J. D., Gibson, T. J., Plewniak, F., Jeanmougin, F. \& Higgins, D. G. (1997). The CLUSTAL_X windows interface: flexible strategies for multiple sequence alignment aided by quality analysis tools. Nucleic Acids Res 25, 4876-4882.

Ventosa, A., Nieto, J. J. \& Oren, A. (1998). Biology of moderately halophilic aerobic bacteria. Microbiol Mol Biol Rev 62, 504-544.

Zeevi Ben Yosef, D., Ben-Dov, E. \& Kushmaro, A. (2008). Amorphus coralli gen. nov., sp. nov., a marine bacterium isolated from coral mucus, belonging to the order Rhizobiales. Int J Syst Evol Microbiol 58, 2704-2709. 